\title{
The glycogen storage diseases
}

\author{
BRENDA E. RYMAN
}

From the Department of Biochemistry, Charing Cross Hospital Medical School, Hammersmith, London

It is now 45 years since von Gierke (1929) first reported his observation at necropsy of a marked accumulation of glycogen in the livers of two patients. Since that time not only has our knowledge of glycogen metabolism undergone major changes but we also now know of at least seven or eight distinct types of glycogen storage disease in which the absence of a single enzyme activity can be demonstrated.

\section{Glycogen Structure and Metabolism}

Glycogen is the polysaccharide which is the main carbohydrate reserve substance of many living organisms, including man, and which is analogous to the starch reserve of the plant kingdom. Glycogen is made of glucose units joined either through $\alpha-1,4$ linkage or 1,6 linkage and, in this way, a polymer is formed which, due to its high molecular weight of many millions, exerts minimal osmotic pressure when compared with a comparable amount of free glucose. Due to the highly branched (1,6 links) nature of the molecule it is extremely soluble and with its large number of chain ends is eminently suitable for rapid attack by exoenzymes in the degradative process leading to its utilization.

All mammalian cells have the capacity to make glycogen and the degree to which glycogen is made and degraded is related to the particular function of the cell. Thus, glycogen is abundant in liver where it is used predominantly to form blood glucose, and in muscle where it is a fuel for muscle contraction. Brain, on the other hand, although utilizing glucose preferentially for its metabolic needs, does not store glycogen to any significant extent. Figure 1 illustrates diagrammatically the probable structure of the glycogen molecule.

The polysaccharide is made by a process of chain elongation occurring at the periphery of the molecule by the sequential addition of glucose units in 1,4 linkage. As the chains grow, the introduction of branch points occurs by the removal of segments of the growing outer chains and their repositioning in the molecule in 1,6 links. This process of chain elongation and branching is achieved by glycogen

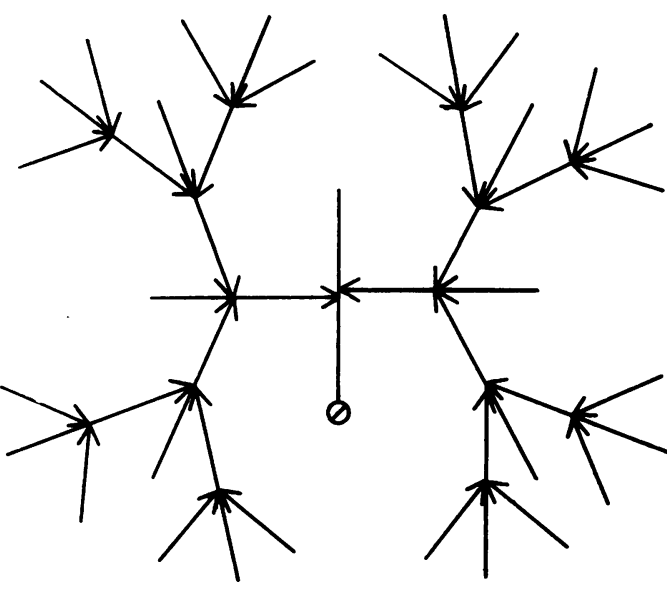

Fig 1 Straight lines represent runs of glucose units joined in 1-4 linkage. Arrow heads represent 1-6 linkages (branch points). $\mathbf{0}=$ reducing end of the molecule.

Redrawn from the paper by Gunja-Smith et al (1970), with permission from FEBS Letters.

synthetase and branching enzyme. Catabolism of the polysaccharide is achieved by the opposite process, ie, chain attenuation and debranching. The chainattenuating enzyme is phosphorylase, an enzyme which again acts on the peripheral chain ends and which leads to the cleavage of the 1,4 linkages to give glucose 1-phosphate. The process of chain shortening continues until a branch point is approached when phosphorylase loses its affinity for the partially degraded glycogen and at this point the glycogen is found to have all its outer chains in the structure indicated below (figure 2a). This is referred to as a limit dextrin of phosphorylase.

Debranching, ie, the removal of the 1,6 links, now occurs by a process involving a transferase followed by a debranching enzyme which hydrolyses the single stub of glucose joined in 1,6 link to give glucose (figure $2 \mathrm{~b}$ ). Once a branch point has been removed phosphorylase is again able to take up its task of chain shortening and the whole process continues until a new branch point is encountered when the 


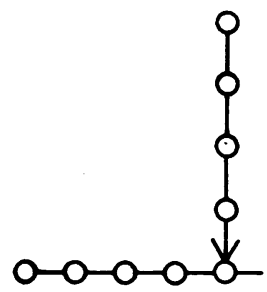

(a)

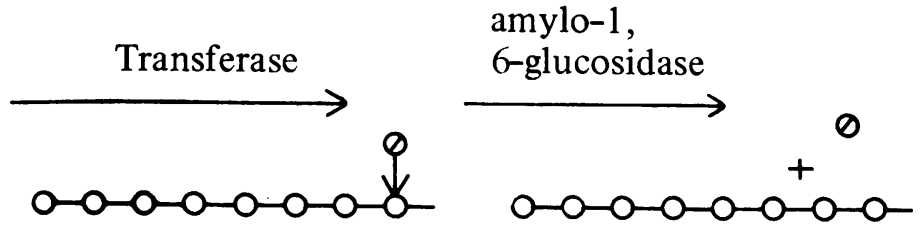

(b)

phosphorylase limit dextrin

Fig 2a Outer chain structure of the glycogen molecule after phosphorylase action.

Fig $2 \mathrm{~b}$ Action of debranching system. $\bigcirc-\bigcirc=$ Glucose units; $\Theta=$ free glucose.

process of transferase/debrancher is repeated. These processes of synthesis and degradation of the polysaccharide occur in the cytoplasm of cells, although the endoplasmic reticulum may also be involved. The phosphorolytic pathway forms the main degradative pathway for glycogen; however, glycogen may be also degraded by $\alpha$-amylases of cells although the significance of this pathway is unknown. In addition, $\alpha$-glucosidases occur in cells and may roughly be divided into those acting at

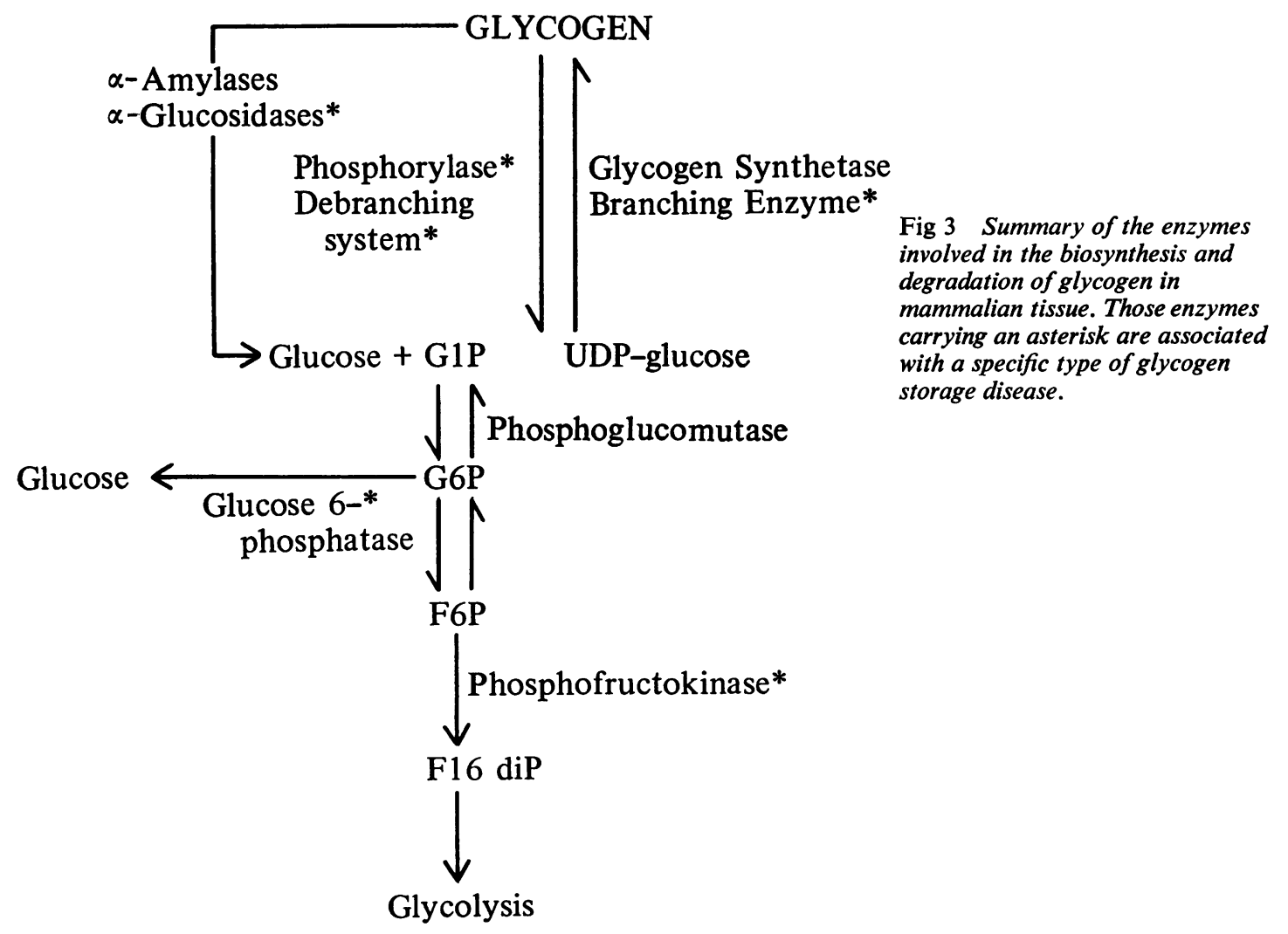


neutral and those acting at acid $\mathrm{pH}$ (Taylor and Whelan, 1968). Hers and his colleagues have pioneered the work on one of these $\alpha$-glucosidases, believed to be of lysosomal origin, which is responsible for the degradation of glycogen reaching the Lack of this acid $\mathrm{pH}$ optimum $\alpha$-glucosidase (sometimes referred to as acid maltase), which is able totally to degrade glycogen to glucose, leads to the fatal glycogen storage disease type II (Pompe's disease). Figure 3 summarizes the enzymic mechanisms which are responsible for glycogen synthesis and degradation and its link to the glycolytic pathway.

\section{Disorders of Glycogen Metabolism}

The enzymes carrying an asterisk in figure 3 are those whose absence, due to a genetic fault, are known to lead to the accumulation of an abnormal amount of glycogen. The accumulated glycogen is frequently of normal structure having, on average, 12 glucose units to each chain peripheral to the branch point. However, in some glycogen storage diseases, for example in type III where the mechanism of debranching is lost, the end product of phosphorylase activity, ie, a phosphorylase limit dextrin, is found where the outer chains of the glycogen molecule will be very short, and thus the overall chain length $(\overline{\mathrm{CL}})$ will be much less than 12 . On the other hand, deficiency of the branching enzyme, which is a very rare defect (type IV glycogen storage disease), results in glycogen resembling amylopectin, a component of starch, the storage product of the plant world. This glycogen is much less branched and has an overall $\overline{C L}$ of about 22 and is much less soluble than normal glycogen. It is probably treated as a foreign substance despite the fact that the cell produced it, and such a hostile reaction may be the basis of the early cirrhosis that is characteristic inside of lysosomes during their normal autophagy.

of this type IV disease. As well as the assessment of the fine structure of the glycogen, iodine staining of the polysaccharide may also give valuable information concerning its structure. The normal peak absorption of the glycogen iodine stain is in the region of $460-480 \mathrm{~nm}$, but this will be modified if the average $\overline{\mathrm{CL}}$ is altered.

Table I summarizes the types of glycogen storage disease that are now recognized and the main tissues affected. The types may be divided loosely into those where the enzymic lesion, and hence the accumulation of polysaccharide, are localized (types I, V, VII), and those where a more generalized distribution amongst tissues is seen (types II, III, IV, VI).

The literature of the glycogen storage diseases is large, and the reader who seeks further information is referred to several reviews which include those by Brown and Brown (1968, types I, III, IV, V, and VII), Hers and Van Hoof (1968, types II and VI), Howell (1972, all types), and Hers and de Barsy (1973, type II).

Table II summarizes some of the clinical symptoms which appear to be relatively characteristic of the individual glycogen storage disease, but it must be emphasized that many others exist and, indeed, not all the symptoms, not even those that are said to be characteristic, always appear in each case. The relative rarity of these disorders, probably in the region of 1 in 70000 live births (Öckerman, 1972; Moe, Garatun-Tjeldstø, Garatun-Tjeldstø, Raae, and Vogt, 1972), at least ensures that well documented clinical descriptions are available, as most glycogen storage disease patients reach the literature in some form or another.

\section{Differentiation of the Glycogen Storage diseases}

The differential diagnosis of the glycogen storage

\begin{tabular}{lll}
\hline Type & Enzyme Defect & Tissues Affected \\
\hline Localized & Glucose-6-phosphatase & Liver, kidney, and small intestine \\
I & Muscle phosphorylase & Striated muscle \\
V & Phosphofructokinase & Muscle \\
McArdle & & \\
VII & & \\
Tarui & & Most tissues, including amniotic cells and leucocytes \\
More Generalized & Lysosomal $\alpha$-glucosidase ('acid maltase') & Several subclasses, but liver and/or muscle most affected \\
II & Debranching enzyme(s) (amylo 1,6-glucosidase/transferase) & Leucocytes \\
Pompe & & Fibroblasts \\
Forbe & Branching enzyme & Liver, leucocytes, and fibroblasts \\
IV & Phosphorylase defect & Liver, leucocytes \\
Andersen & & \\
VI & &
\end{tabular}

Table I Glycogen storage diseases 


\begin{tabular}{|c|c|}
\hline Type and Defect & Main Symptoms \\
\hline $\begin{array}{l}\text { Localized } \\
\text { I } \\
\text { (Von Gierke-glucose-6-phosphatase) } \\
\text { V } \\
\text { (McArdle-muscle phosphorylase) } \\
\text { VII } \\
\text { (Tarui-muscle phosphofructokinase) }\end{array}$ & $\begin{array}{l}\text { Massive hepatomegaly, severe hypoglycaemia, acidosis, } \uparrow \text { serum lipids, serum lactate and } \\
\text { uric acid } \\
\text { Easy fatigueability, painful cramps after strenuous exercise } \\
\text { Myoglobinuria } \\
\text { As in type V }\end{array}$ \\
\hline $\begin{array}{l}\text { More Generalized } \\
\text { II } \\
\text { (Pompe-lysosomal } \alpha \text {-glucosidase) } \\
\text { III } \\
\text { (Forbe-debranching enzyme(s)) } \\
\text { IV } \\
\text { (Andersen-branching enzyme) } \\
\text { VI } \\
\text { (Hers-phosphorylase defect) }\end{array}$ & $\begin{array}{l}\text { Massive cardiomegaly in infants, hypotonia without wasting } \\
\text { Massive hepatomegaly, variable hypoglycaemia, and in general similar to type I } \\
\text { Progressive cirrhosis with hepatosplenomegaly and ascites } \\
\text { Mild hepatomegaly, mild hypoglycaemia }\end{array}$ \\
\hline
\end{tabular}

Table II Glycogen storage diseases

diseases almost always requires direct enzyme assay on some suitable tissue, and diagnosis without such direct assay is not wholly satisfactory. There are, however, several useful tests that may be carried out to aid diagnosis, and these include: (1) ability of the patient to respond to glucagon or adrenaline as measured by an increase in blood glucose and the effect of these hormones on blood lactate; (2) infusion of galactose which, in the normal state, results in conversion to glucose and an increase in blood glucose; (3) measurement of blood lactate following ischaemic exercise, as described by McArdle (Gruener, McArdle, Ryman, and Weller, 1968); (4) measurement of blood lactate following a glucose tolerance test (Fernandes, Huijing, and van de Kramer, 1969); (5) assessment of relative half lives of $\left(2^{3} \mathrm{H}\right)$-glucose compared with $\left(\mathrm{U}^{14} \mathrm{C}\right)$-glucose (Hue and Hers, 1972).

Öckerman (1967) and Spencer-Peet, Norman, Lake, McNamara, and Patrick (1971) have discussed the usefulness of tests 1,2 , and 4 in assessing hepatic glycogenoses. Paraffin sections of tissues are not very

\begin{tabular}{|c|c|c|}
\hline Type and Defect & Tests for Diagnosis & Severity \\
\hline \multicolumn{3}{|c|}{ 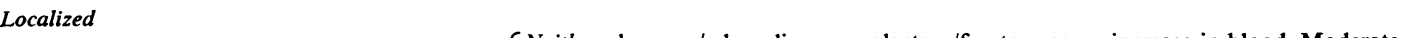 } \\
\hline $\begin{array}{l}\text { I } \\
\text { (Von Gierke-glucose-6-phosphatase) }\end{array}$ & $\left\{\begin{array}{l}\text { Neither glucagon/adrenaline nor galactose/fructose cause increase in blood } \\
\text { glucose levels } \\
\text { High blood lactate reduced on glucose administration } \\
\text { Comparison of half lives of }\left(2^{3} \mathrm{H}\right) \text {-glucose with }\left(\mathrm{U}^{14} \mathrm{C}\right) \text {-glucose } \\
\text { Liver biopsy } \uparrow \text { glycogen and absence of glucose-6-phosphatase }\end{array}\right.$ & Moderate \\
\hline $\begin{array}{l}\text { V } \\
\text { (McArdle-muscle phosphorylase) }\end{array}$ & $\left\{\begin{array}{l}\text { No rise in venous lactate after ischaemic exercise } \\
\text { Muscle biopsy } \uparrow \text { glycogen and absence of phosphorylase }\end{array}\right.$ & Mild \\
\hline $\begin{array}{l}\text { VII } \\
\text { (Tarui-muscle phosphofructokinase (PFK)) }\end{array}$ & $\begin{array}{l}\text { No rise in venous lactate after ischaemic exercise } \\
\text { Erythrocyte PFK diminished } \\
\text { Muscle biopsy } \uparrow \text { glycogen and absence of PFK }\end{array}$ & Mild \\
\hline \multicolumn{3}{|l|}{ More Generalized } \\
\hline $\begin{array}{l}\text { II } \\
\text { (Pompe-lysosomal } \alpha \text {-glucosidase) }\end{array}$ & $\begin{array}{l}\text { Biopsies (muscle, liver, skin etc) show } \uparrow \text { glycogen and lack of } \\
\alpha \text {-glucosidase } \\
\text { Leucocytes usually show defect, also amniotic cells }\end{array}$ & Lethal \\
\hline $\begin{array}{l}\text { III } \\
\text { (Forbe-debranching enzyme(s)) }\end{array}$ & $\left\{\begin{array}{l}\text { Glucagon/adrenaline give } \uparrow \text { blood glucose in fed state but not in fasted } \\
\text { Galactose/fructose infusion } \uparrow \text { blood glucose } \\
\text { Blood lactate level } \uparrow \text { after glucose load } \\
\text { Erythrocyte glycogen elevated and enzyme defect in muscle and/or liver, } \\
\text { and usually in blood cells and fibroblasts } \\
\text { Glycogen structure abnormal in fasted state (short outer chains) }\end{array}\right.$ & Mild \\
\hline $\begin{array}{l}\text { IV } \\
\text { (Andersen-branching enzyme) }\end{array}$ & $\left\{\begin{array}{l}\text { Liver biopsy shows cirrhosis and } \uparrow \text { glycogen of abnormal structure } \\
(\bar{C} L 22 \text { instead of } 12) \\
\text { Lack of branching enzyme in liver leucocytes and fibroblasts }\end{array}\right.$ & Lethal \\
\hline $\begin{array}{l}\text { VI } \\
\text { (Hers-phosphorylase defect) }\end{array}$ & $\left\{\begin{array}{l}\text { Increase in blood lactate after glucose load. Normal glucose elevation } \\
\text { following glucagon or galactose } \\
\text { Examination of liver biopsy and leucocytes for phosphorylase and } \\
\text { phosphorylase kinase activities }\end{array}\right.$ & Very mild \\
\hline
\end{tabular}

Table III Glycogen storage diseases 


\begin{tabular}{|c|c|c|}
\hline & A.R. & Normal \\
\hline $\begin{array}{l}\text { Glycogen level } \\
\mathrm{g} / 100 \mathrm{~g} \text { wet weight of tissue }\end{array}$ & $4 \cdot 1$ & $<0.2$ \\
\hline $\begin{array}{l}\mathrm{g} / 100 \mathrm{~g} \text { wet weight of tissue } \\
\text { Debranching enzyme and transferase } \\
\mu \text { moles glucose released from phosphorylase limit dextrin } \min ^{-1} \mathrm{~g}^{-1} \text { tissue }\end{array}$ & 0 & $0 \cdot 68$ \\
\hline $\begin{array}{l}\mu \text { moles glucose released trom phosphorylase limit dextrin min } \\
\text { Debranching enzyme } \\
\mu \text { moles glucose released from 6-glucosyl- } \alpha \text {-Shardinger dextrin } \min ^{-1} \mathrm{~g}^{-1} \text { tissue }\end{array}$ & 0 & 0.5 \\
\hline Acid maltase & 0.13 & $0.03-0.11$ \\
\hline $\begin{array}{l}\mu \text { moles maltose hydrolysed } \min ^{-1} \mathrm{~g}^{-1} \text { tissue } \\
\text { Glycogen phosphorylase } \\
\mu \text { moles inorganic phosphate released from glucose } 1 \text {-phosphate } \min ^{-1} \mathrm{~g}^{-1} \text { tissue }\end{array}$ & 123 & $50-100$ \\
\hline 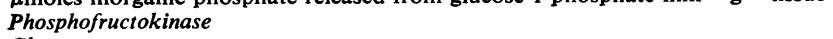 & Present & \\
\hline $\begin{array}{l}\text { Glycogen structure } \\
\text { Iodine stain, maximum absorption wavelength }(\mathrm{nm})\end{array}$ & $\lambda \max 495$ & $440-500$ \\
\hline
\end{tabular}

Table IV Muscle biopsy (A.R. 1973) ${ }^{1}$

${ }^{1}$ Biopsy data from child with type III glycogen storage disease showing defect of both transferase (phosphorylase limit dextrin substrate) and debranching enzyme (Shardinger dextrin substrate) (patient of Professor V. Dubowitz, Hammersmith Hospital).

\begin{tabular}{|c|c|c|c|}
\hline \multirow{2}{*}{$\frac{\text { Type }}{\text { I }}$} & \multicolumn{3}{|l|}{ Subtype } \\
\hline & Ia & $\begin{array}{l}\text { Ib } \\
\text { (enzyme not } \\
\text { inactive but } \\
\text { classical } \\
\text { symptoms) }\end{array}$ & \\
\hline II & $\begin{array}{l}\text { IIa } \\
\text { (infantile) }\end{array}$ & $\begin{array}{l}\text { IIb } \\
\text { (adult) }\end{array}$ & \\
\hline III & IIIa & IIIb & IIIC IIId \\
\hline $\begin{array}{l}\text { VI phosphorylase } \\
\text { defect }\end{array}$ & VIa & VIb & \\
\hline $\begin{array}{l}\text { IX phosphorylase } \\
\text { kinase }\end{array}$ & $\begin{array}{l}\text { IXa } \\
\text { (normal Km) }\end{array}$ & $\begin{array}{l}\text { IXb } \\
(\uparrow \mathrm{Km})\end{array}$ & \\
\hline
\end{tabular}

Table $\mathrm{V}$ Variants of types of glycogen storage diseases.

suitable for the diagnosis of glycogen storage diseases as the glycogen (particularly the short outer chained material found in type III) readily washes out of formol-saline-fixed material.

Over the last 20 years, and since the demonstration that polymorphonuclear leucocytes could accumulate glycogen, much work has been done to investigate the possibility of utilizing white cells and, indeed, also erythrocytes, for the diagnosis of glycogen storage disease, thereby avoiding liver or muscle biopsy. While this technique of enzyme assay on leucocytes may be, without question, most useful, there are many reports in the literature where the enzyme defect shown in other tissues was not mirrored in the leucocytes. It would seem, in view of this, that leucocytes, together with other more readily available tissues, are probably useful in family studies and genetic work, but that the primary diagnosis in a family is best done by direct assay on the main affected tissue-muscle or liver-based on the clinical findings.

Table III summarizes the tests which are useful in diagnosing each of the glycogen storage diseases. The detailed enzyme studies on various tissues from glycogen storage disease patients have undoubtedly increased our understanding of these disorders, but they have also unquestionably increased the complexity of the situation and most types are now subdivided, and examples of this situation are shown in table V. (Further reference will be made to these subtypes later.) All the groups so far studied, with the exception of type VIa, suggest that the glycogen storage diseases are inherited by an autosomal recessive type of inheritance. Huijing and his collaborators (see types VI, VIII, and XI) have studied type VIa and have concluded that the disorder is inherited in an X-linked manner.

Methodology for the enzyme investigation of biopsies and leucocytes is well documented, eg, Hers (1964), Huijing (1967), Öckerman (1968), Lundquist and Öckerman (1970), and Spencer-Peet et al (1971).

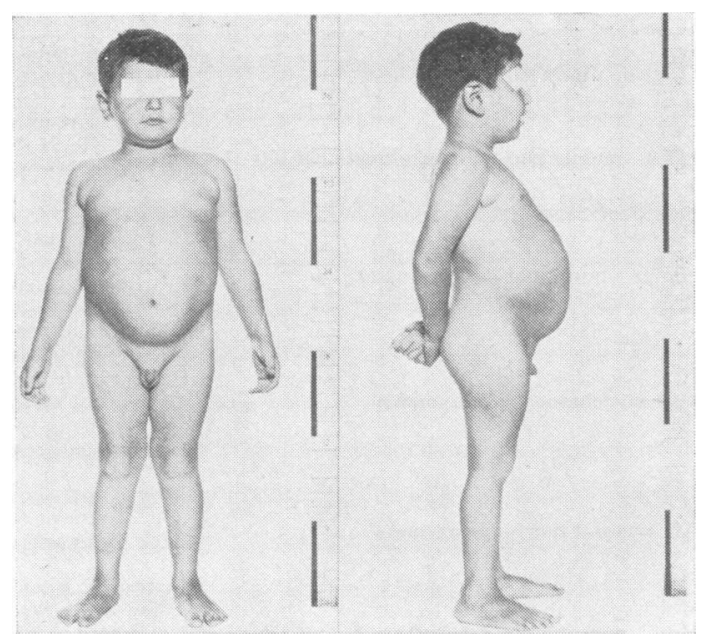

Fig 4 Boy with type III glycogen storage disease showing grossly enlarged liver (patient of Professor Sheila Sherlock, Royal Free Hospital, London) 


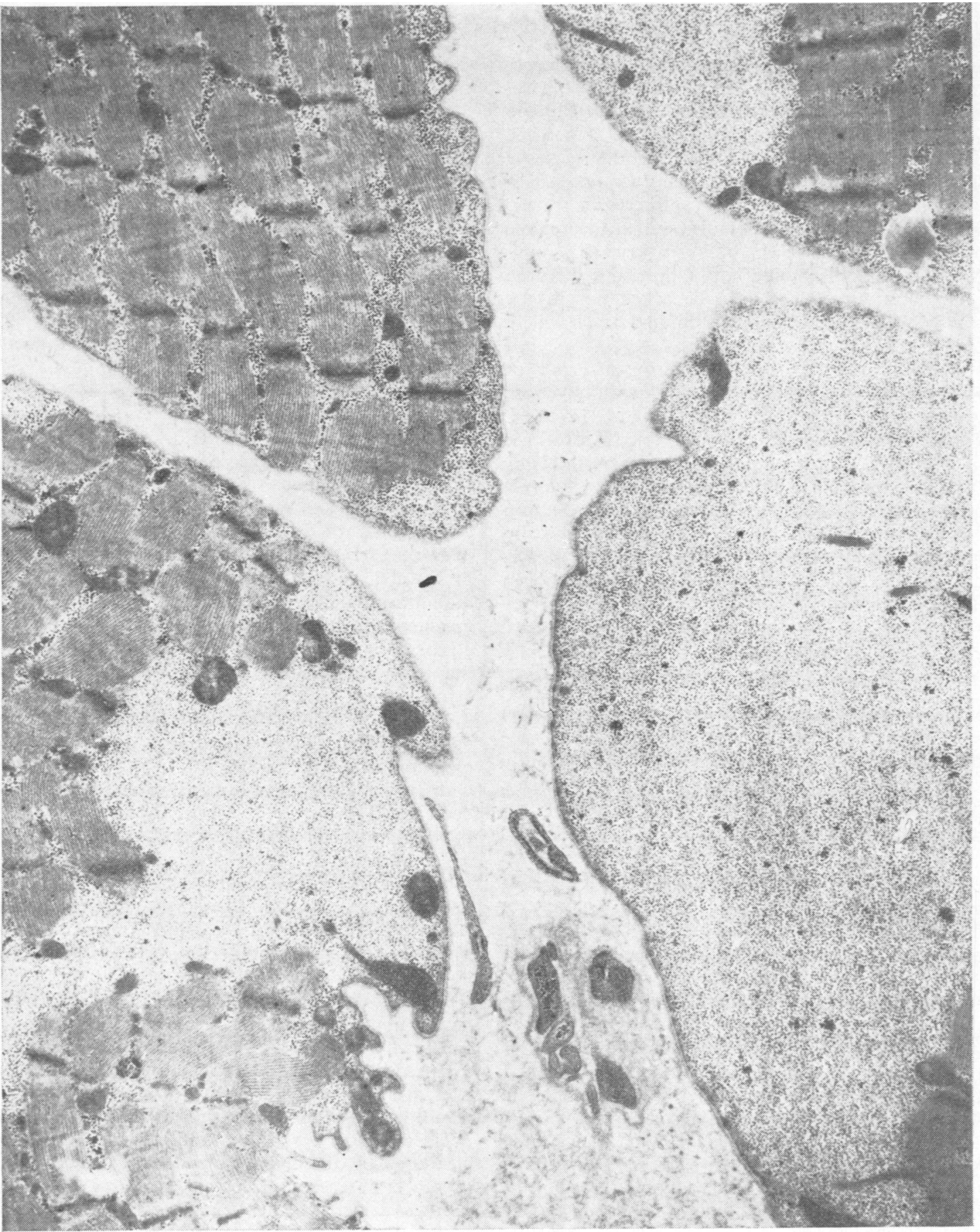

Fig 5 Electron micrograph of muscle tissue from a baby with type III glycogen storage disease, in which a large accumulation of glycogen can be seen in the sarcoplasm (patient of Professor V. Dubowitz, Hammersmith Hospital, London). The electron micrographs were kindly prepared by Mrs Caroline Maunder. 
It is, however, essential that such work is carried out in a laboratory by workers fully familiar with the methods. Biopsy material must be handled extremely carefully since some enzymes (glucose-6-phosphatase, for example) are very labile. Biopsy data which state the absence of more than one enzyme sometimes reflect poor handling of the material. Biopsy tissue should be frozen immediately and wrapped in a small piece of aluminium foil and kept in a deep freeze in a small sealed container so that the volume of air in contact with the biopsy is kept to a minimum. The sample should not be thawed and frozen again, and surgeons should be asked not to use glove powder: this frequently contains starch which, on assay, behaves like glycogen.

Figure 4 shows (by kind permission of Professor Sheila Sherlock, London) a child with glycogen storage disease where the liver is mainly involved. Typical biopsy data are shown in table IV for a case of type III glycogen storage disease where the baby showed symptoms of floppiness with some enlargement of the heart. This child's muscle electron micrograph is shown in figure 5 (by kind permission of Professor V. Dubowitz, London), and clearly displays the large amount of accumulated glycogen in the sarcoplasm.

\section{Glycogen Storage Diseases}

While so many excellent reviews (listed previously) exist in the literature, it would seem to the writer that only recent imformation, or that not readily available in the review articles, should be discussed, and this will be done briefly under each type of glycogen storage disease.

\section{TYPE I (GLUCOSE-6-PHOSPHATASE}

DEFICIENCY)

This disorder is well documented by Howell (1972) and by Brown and Brown (1968). One of the major clinical symptoms, namely, hypoglycaemia, appears to be a constant finding in this disorder, and it is most surprising that some children whose blood glucose falls below $10 \mathrm{mg}$ per $100 \mathrm{ml}$ do not show the expected convulsions. A likely explanation seems to be that, like the obese-starved individual (Owen, Morgan, Kemp, Sullivan, Herrera, and Cahill, 1967), the brains of children with type I can utilize ketone bodies in preference to glucose. The urine of type I children sometimes contains abnormal quantities of glucose, inorganic phosphate, and amino acids, and it is believed that this may be associated with kidney dysfunction associated with the lack of glucose-6-phosphatase in this tissue, leading to glycogen accumulation and maybe impaired renal transport. Osteoporosis in type I patients has been reported, and this may reflect the phosphate loss coupled with the acidosis which is a feature of this disorder.

Type I children have a defect in bleeding, although the factors involved are not clearly defined (Lowe, Ambrus, Ambrus, Mosovich, Mink, and Sokal, 1960). Steatorrhoea is also commonly found in type I, but this does not appear to be associated with malabsorption (Howell, Ashton, and Wyngaarden, 1962). Recently Fine, Wilson, and Donnell (1968) have reported discrete paramacular lesions of the fundus of the eye in three out of five of their patients with type I glycogen storage disease. The hyperlipidaemia of this disorder is associated with increased levels of triglyceride, phospholipids, and cholesterol (Howell et al, 1962), as well as glycerol (Öckerman, $1965 \mathrm{a}$ and b). In view of the low insulin status of type I patients (Lockwood, Merimee, Edgar, Greene, Fujimoto, Seegmiller, and Howell, 1969), it is tempting to speculate that the low level of blood glucose, together with the expected high level of glucagon (see Epand and Douglas, 1973, and references therein), will stimulate the hormonesensitive lipase of adipocytes and cause fatty acid mobilization. On the other hand, the possible increased flux of glucose-6-phosphate through glycolysis and the pentose pathway may account for the increased synthesis of fat and cholesterol as evidenced in this disorder by adiposity and xanthomas in the skin. Cuttino, Hill, and Summer (1970) have observed from their work that a diet containing medium-chain triglycerides led, in a 7-year-old boy with type I glycogen storage disease, to a marked decrease in serum lipids within 14 days of starting the diet, and a complete disappearance of xanthomas in four months. As well as the insulin status of type I patients, other hormonal aspects of this disorder have been examined by Bierich, Rager, and Schönberg (1973), who report that several aspects of the symptoms observed in type I may be accounted for by changes in cortisol and growth hormone level.

It has been suggested that the increased blood lactate in this disorder may also be a reflection of a greater flux through glycolysis due to the blockage imposed by glucose-6-phosphatase deficiency. However, it seems unlikely that such a naïve view will stand the test of further experimentation. Blood uric acid elevation is probably a reflection of a diminished clearance by the kidney of this substance in the presence of increased lactate and, maybe, other organic acids. Another suggestion to explain the raised uric acid involves a possible increased production mediated by a raised formation of phosphoribosyl pyrophosphate (Kelley, Rosenbloom, Seegmiller, and Howell, 1968) secondary to an increased 


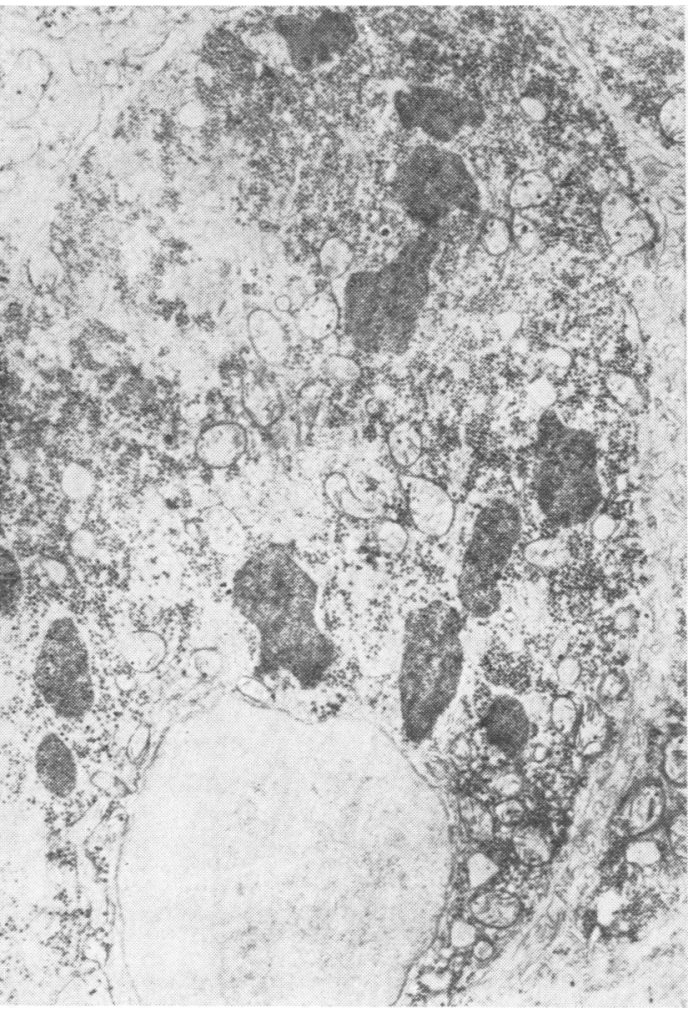

Fig. 6a.

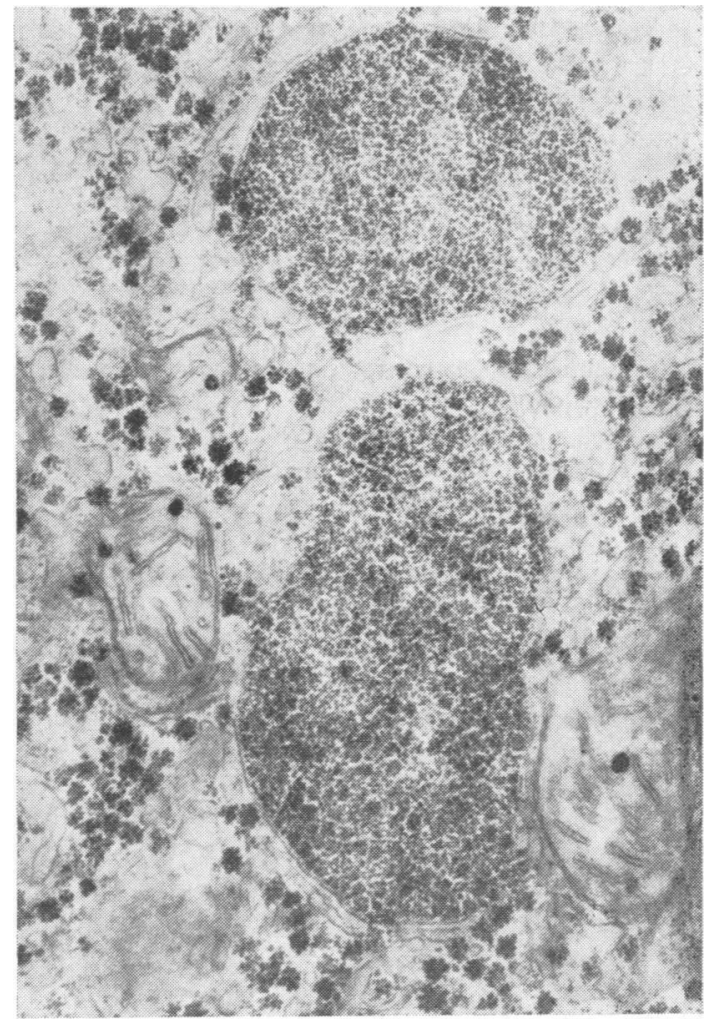

Fig. 6b

Fig 6 Electron micrograph of liver tissue of a child with type II glycogen storage disease, taken from the paper by Baudhuin, Hers, and Loeb (1964), and reproduced by permission of Laboratory Investigation.

The dark areas in a represent accumulated glycogen which, on further magnification $b$, can be seen to be membrane surrounded.

flux through the pentose pathway, leading to greater ribose production. It is, perhaps, of some interest to note that Dosman, Crawhill, Klassen, Mamer, and Neumann (1972) have reported the appearance of short-chain fatty dicarboxylic acids (suberic, azelaic, sebacic, and adipic) in the urine of type I patients, and these acids diminish on the administration of allopurinol. Although ketosis (as well as acidosis) has been generally considered to be a characteristic of type I, Fernandes and Pikaar (1972) reported recently that ketosis does not seem to be a feature of glucose-6-phosphatase deficiency.

In his recent review Howell (1972) has discussed treatment of type I glycogen storage disease children, as have Spencer-Peet et al (1971). Variants (or subclasses) of type I glycogen storage diseases have recently been reported. Grenet, Badoual, Lestradet, Marinetti, Sanna, and Voyer (1972), Badoual, Lestradet, Tichet, Sanna, and Grenet (1972), and
Moses (1973) have reported cases of glycogenosis with repeated hypoglycaemia, hyperuricaemia, and marked hyperlipidaemia with normal glucose-6phosphatase activity, and Moses (1973) has suggested a classification of type Ib for such children. It would, however, seem to the writer that it is too early to make a special subclass for so few patients.

\section{TYPE II (LYSOSOMAL 'ACID MALTASE'} DEFICIENCY)

The excellent review of type II glycogenosis by Hers and de Barsy (1973) is strongly recommended to the reader, together with articles by Hers and Van Hoof (1968) and Howell (1972).

Classical infantile type II glycogenosis has a very poor prognosis, and children with this disorder usually die with cardiomegaly and hypotonia in the first few months of life. Glycogen accumulates in many tissues (around 10\% in muscle-normal 1\%) 


\begin{tabular}{lll}
\hline & IIa (Infantile) & Ilb (Adult) \\
\hline $\begin{array}{l}\alpha \text {-Glucosidase } \\
\text { deficiency }\end{array}$ & Marked & Marked \\
$\begin{array}{l}\text { Glycogen content of } \\
\text { tissues }\end{array}$ & Marked & $\begin{array}{l}\text { Normal or slight } \\
\text { Abncrease }\end{array}$ \\
Prognosis & $\begin{array}{l}\text { Abundant and } \\
\text { large }\end{array}$ & Poor-early death and few \\
\hline
\end{tabular}

Table VI Type II glycogen storage disease (Pompe's disease) variants

within membrane-bound structures which are believed to be lysosomes. Cytoplasmic glycogen is either normal in amount or increased. Electron micrographs of tissue from children with type II disease have been published by many authors, but few are as distinguished as the early publications of Baudhuin, Hers, and Loeb (1964). Figure 6 shows two such pictures from their work.

A variant of this disorder (adult form, table VI) shows a lack of enzyme activity, but the symptoms and prognosis are much less severe, and hepatomegaly and cardiomegaly are usually not a feature. Muscle weakness and wasting are observed. Several reports of this variant have appeared in the literature (eg, Courtecuisse, Royer, Habib, Monnier, and Demos, 1965; Roth and Williams, 1967; Hudgson, Gardner-Medwin, Worsfold, Pennington, and Walton, 1968; Engel, 1970; Canal, Frattola, and Pellegrini, 1972).

While there seems little doubt in most people's minds that the defect involves the $\alpha$-glucosidase associated with lysosomes, the majority agree that there are aspects of the disorder which are still not clear, including the co-accumulation with glycogen of another substance which may be an acidic mucopolysaccharide. Ultrastructural and biochemical studies (Garancis, 1968; Bruni and Paluello, 1970 ) indicate that in heart the glycogen does not appear to be membrane bound. de Barsy, Jacquemin, Devos, and Hers (1972) were unable to detect any protein immunologically (using an antiserum to $\alpha$-glucosidase) in tissues from type II glycogenosis using a double-diffusion technique or antibody consumption test.

Diagnosis of type II disease is achieved by direct assay of tissue such as liver, muscle, or skin (Leathwood and Ryman, 1971). Cultured fibroblasts (see Brown and Brown, 1972; and DiMauro, Rowland, and Mellman, 1973) appear to be suitable for enzyme analysis, and furthermore show an accumulation of glycogen in vacuoles (Hug, Schubert, and Soukup, 1971). Leucocyte assays (Huijing, 1967) have given equivocal results, and this may reflect the differing ways of isolating leucocytes that have been used, eg, centrifugation alone, or after prior sedimentation of erythrocytes with dextran, since different methods appear to yield varying proportions of the different white cells in blood. Hers and de Barsy (1973) caution against the use of leucocytes and amniotic cells (Nadler and Messina, 1969; Salafsky and Nadler, 1971); they point out that these cells have an $\alpha$-glucosidase which is not inhibited by turanose (a characteristic of the $\alpha$-glucosidase missing in type II), and that this $\alpha$-glucosidase activity may confuse the assay. Urine also seems to be a possible specimen for assay since it also contains an $\alpha$-glucosidase which is missing in type II.

This type of glycogenosis, which is lethal in the infantile form, is inherited by an autosomal recessive mode of inheritance, and Hers and his collaborators (Hers and de Barsy, 1973) believe that the incidence of the disorder is probably in the order of 1 in 150000 . Early experiments with amniotic cells suggest that accumulated glycogen can be seen in the electron microscope in such cells from fetuses at risk (Hug, Schubert, and Soukup, 1970c), and while studies on $\alpha$-glucosidase activity in cultured amniotic cells in this disorder have not been without their problems, there seems little doubt that such an approach will be successful, and that early diagnosis in utero of type II will be available.

\section{TYPE III (DEBRANCHING ENZYME}

DEFICIENCY)

Forbe's 'limit dextrinosis' (for reviews see Howell, 1972; Brown and Brown, 1968) derives its name from the fact that, due to the lack of debranching activity, the structure of the glycogen isolated from tissues of patients suffering from this disorder resembles the phosphorylase limit dextrin depicted in figure 2. The glycogen structure usually, but not always, has short outer chains, and hence lower $\overline{\mathrm{CL}}$, and this is particularly seen if the tissues are studied after overnight fasting. The iodine spectrum of the glycogen shows a shift in optimum absorbance associated with the shorter outer chains.

Although the disorder resembles type I in many of its features it can readily be distinguished by direct assay of the debranching enzyme(s) in many tissues including erythrocytes, where an elevated glycogen level is found (van Hoof, 1967), leucocytes (Huijing, 1967), and fibroblasts (DiMauro et al, 1973). However, atypical results have been reported (Deckelbaum, Russell, Shapira, Cohen, Agam, and Gutman, 1972). In contrast to type I, the positive galactose glucose test, the responsiveness to glucagon in the fed state (but not so in the fasted state), the elevation of blood lactate after a glucose load, and the preferential loss of the tritium label from $\left(2^{3} \mathrm{H}\right)$-glucose compared with $\left(\mathrm{U}^{14} \mathrm{C}\right.$ )-glucose (see table III), are all characteristic of type III glycogenosis. 
Type III is generally regarded as milder than type I, with hepatomegaly, mild hypoglycaemia, sometimes splenomegaly with variable elevation of blood lipids, and a usually normal uric acid level. Serum transaminases are consistently elevated (cf type I where they are very often normal). Although type IV glycogen storage disease is the one type where cirrhosis is invariably found, a few reports of cirrhosis in type III have been recorded (Starzl, Marchioro, Sexton, Illingworth, Waddell, Faris, and Herrmann, 1965; Brandt and DeLuca, 1966).

The two components of the debranching system (transferase and amylo-1,6-glucosidase) have been discussed, and their action is summarized in figure 2. van Hoof and Hers (1967) have studied some 40 cases of type III by varying techniques which distinguish between the two components of the debranching system, and have concluded that two main variants exist in which both the enzymes are missing in the liver and muscle-IIIa, or in muscle alone-IIIb. A further four subclasses, which are very rare, accommodate cases where the two components of the debranching process occur in various combinations and permutations between liver and muscle tissue.

Type III is believed to be one of the commoner of the glycogen storage diseases, and in a study made in Israel (Levin, Moses, Chayoth, Jagoda, and Steinitz, 1967) it was reported to have an incidence of 1 in 5420 in a non-Ashkenazi Jewish community originating from North Africa. Type III appears to be inherited as an autosomal recessive, and the genetics of this disorder, as well as the other types of glycogen storage disease, have been considered by Sidbury (1965). Attempts to show a gene dosage effect expressed by diminished levels of the enzyme in the heterozygous state have given equivocal results. The genetics of type III have also been studied by Williams and Field (1968), by Huijing, Obbink, and Creveld (1968), and Waaler, Garatun-Tjeldstø, and Moe (1970).

The prognosis of Forbe's limit dextrinosis is usually good; a high-protein diet with frequent feeding is recommended by Fernandes and van de Kramer (1968) for children with symptoms. Both in this type and in types I and IV, portacaval transpositions and portacaval shunts have been attempted with mixed success (Starzl et al, 1965; Riddell, Davies, and Clark, 1966; Levin, Burgess, and Mortimer, 1968; Starzl, Brown, Blanchard, and Brettschneider, 1969; Hermann and Mercer, 1969).

Muscle wasting is not usually significant in most type III patients, although Brunberg, McCormick, and Schochet (1971) have reported a case in an adult who showed such symptoms. The patient of Professor Dubowitz, reported earlier (see table IV and figure
5), showed some cardiac enlargement which, while not a common feature, has been reported in a few cases (Miller, Alleyne, and Brooks, 1972). It is perhaps of some interest that Moe, Waaler, and Garatun-Tjeldstø (1972) have reported the development of diabetes mellitus-also believed to be an

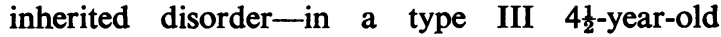
Norwegian boy.

The hyperlipidaemia in type III is discussed by Fernandes and Pikaar (1969), and a four-year follow-up study on the hyperlipidaemia of a type III child has been published by Vítek, Šráčková, Toman, Krátský, and Vognárek (1970).

\section{TYPE IV (BRANCHING ENZYME}

DEFICIENCY)

This disease, known as Andersen's amylopectinosis, is a very rare disorder and there are only seven definite cases and four probable ones reported in the literature. Brown and Brown (1968), Schochet, McCormick, and Zellweger (1970), Schochet, McCormick, and Kovarsky (1971), and Zellweger, Mueller, Ionasescu, Schochet, and McCormick (1972), have documented most of the cases. Two necropsy cases have been recently reported from Japan (Motoi, Sonobe, Ogawa, Murakami, Yamanouchi, Toda, Okamoto, and Ohara, 1973), although no analyses on biopsy material were available. As the name suggests, the glycogen deposited has a low degree of branching and a $\overline{\mathrm{CL}}$ of about 22 (cf normal 12). The presence of branch points $(1 \rightarrow 6$ links) in the molecule is, at first glance, amazing, since the defect is associated with lack of branching enzymes. Evidence suggests that the branch points are achieved by the reversibility of the debranching system (Huijing, Lee, Carter, and Whelan, 1970; Mercier and Whelan, 1970).

The disease is accompanied by symptoms which include failure to thrive, hepatomegaly, splenomegaly, hypotonia, progressive cirrhosis of the liver, and early death. Only one child has survived to the age of 4 years. Heart disease is usually found, and liver disturbance, as assessed by serum transaminase levels, is evident. Although the patient described by Fernandes and Huijing (1968) showed an elevated liver glycogen $(10.7 \%$, cf normal up to $5 \%)$, other authors have not observed raised glycogen.

Skin fibroblasts in type IV glycogen storage disease (Brown and Brown, 1972) show the genetic defect, and the disorder can almost certainly be diagnosed by amniocentesis. Leucocytes have also been used to establish the diagnosis. Portacaval shunt has been attempted in a type IV child (Levin et al, 1967), as has the administration of a fungal $\alpha$-glucosidase (Fernandes and Huijing, 1968) in an attempt to degrade accumulated polysaccharide. 
Kaijser (1966) did not find lowered leucocyte phosphorylase a constant feature of the patients they studied. It must be pointed out that Huijing (1967) has emphasized that assays for phosphorylase activity in leucocytes must be conducted in the total absence of AMP if meaningful data are to be obtained. Hug and his colleagues have reported several patients where the defect involves the differing aspects of the cascade of enzymes discussed above, and they have classified them accordingly:-

\section{TYPE VIII}

Glycogen storage disease characterized by degenerative brain disease and by lack of proper activation of the hepatic phosphorylase system whose enzyme components appear to be normal (Hug, Garancis. Schubert, and Kaplan, (1966). A similar case has been documented by Ludwig, Wolfson, and Rennert (1972).

\section{TYPE IX}

This type (Hug, Schubert, and Chuck, 1966 and 1969, Morishita, Nishiyama, Yamamura, Kodama, Negishi, Matsuo, Matsuo, and Nishizuka, 1973) denotes deficiency of phosphorylase kinase in liver and low phosphorylase in this tissue. The muscle enzymes are normal. This group has been further subdivided by Hug, Sper, and Schubert (1973) into IXa, in which the kinase, while diminished in amount, has a normal $\mathrm{K}_{\mathrm{m}}$, and type IXb, where again it is diminished and also shows a change in $\mathrm{K}_{\mathrm{m}}$. This type IX group will surely eventually be combined with Huijing's subgroup VIa. Hug, Schubert, and Chuck $(1970 \mathrm{~b})$ have described yet another possible type in the phosphorylase defect which is characterized by accumulation of glycogen in both muscle and liver and involving the loss of cyclic $3^{\prime} 5^{\prime}$ AMPdependent kinase in muscle.

Studies on fibroblasts of type VI patients have been made (see Brown and Brown, 1972). Recently Mathieu, Collombel, and Cotte (1972) have indicated that these cells from patients with type VI do not show low phosphorylase activity.

Koster, Fernandes, Slee, van Berkel, and Hülsmann (1973) have reported a biochemical study on the hepatic phosphorylase deficiency, and have put forward diagnostic procedures for the differential diagnosis of phosphorylase and phosphorylase kinase deficiency.

TYPE VII (MUSCLE PHOSPHOFRUCTOKINASE DEFICIENCY)

Tarui, Okuno, Ikura, Tanaka, Suda, and Nishikawa (1965) first described this glycogenosis which, while resembling type $\mathrm{V}$ very closely in its clinical features, nevertheless is associated with a total lack of muscle phosphofructokinase (the key enzyme of glycolysis), and with an elevation of glycogen in muscle. The increase of glycogen is thought to arise partly from the block in the glycolytic pathway, but also maybe from enhanced synthesis, as the authors observed an increased activity of both UDPG pyrophosphorylase and glycogen synthetase. Layzer, Rowlands, and Ranney (1967) have described a patient with this rare disorder, which appears to be inherited as an autosomal recessive. They have shown that there was no cross reaction between the muscle extract from the patient and an antibody raised against human phosphofructokinase, indicating an absence of the enzyme rather than the production of an inactive protein. The phosphofructokinase activity of erythrocytes shows at least two isoenzymes, one of which is the muscle type; the erythrocyte phosphofructokinase of the type VII patients and their relatives appears to be reduced.

\section{UNCLASSIFIED GLYCOGEN STORAGE \\ DISEASES}

Dykes and Spencer-Peet (1972) have reported further studies on a patient which they earlier documented as having marked hypoglycaemia, low levels of liver glycogen, and a lack of glycogen synthetase in this tissue. A deficiency of phosphoglucomutase in muscle was reported by Thomson, MacLaurin, and Prineas (1963). Shen, Edstrom, and Larner (1972) have reported an unusual glycogen storage disease in which the glycogen present is not only in excess but has a very poor primer activity in the synthetase reaction and that, in consequence, there is a build up of glycogen of a low molecular weight which does not exert the normal inhibitory action on glycogen accumulation.

\section{Conclusions}

The milestone for accurate laboratory diagnosis of the glycogen storage disease has surely been reached. Suitable sensitive techniques, specific substrates, and care with biopsies results in accurate diagnosis. Once a diagnosis is firmly established, suitable treatment to counteract unwanted symptoms can be instigated (see Spencer-Peet et al, 1971). What then for the future if we are to move forward? The two glycogen storage diseases, types II and IV, present us with the greatest challenge as, without further advances, these children will die in the first year in the case of type II and in the first two years of their life in the case of type IV.

Severe type I cases will remain a risk and a problem to their parents to look after since their feeding 
regime, necessary to counteract the hypoglycaemia, is demanding both day and night. A recent report by Tze, Crigler, and Folkman (1972) of a constant glucose infusion pump for the maintenance of blood glucose in cases of type I glycogen storage disease has been greeted with enthusiasm, and looks hopeful to overcome the problem of delayed growth in these children which Fine, Frasier, and Donnell (1969) have suggested is due, in part, to low glucose levels. Portacaval shunts to bypass the liver and thereby, hopefully, to avoid further glycogen deposition are receiving further attention and look promising coupled with prolonged hyperalimentation before surgery (Folkman, Philippart, Tze, and Crigler, 1972). The platelet defect observed in type I may also respond to such hyperalimentation (Czapek, Deykin, and Salzman, 1972).

Genetic engineering, regarded by many as highly undesirable will, however, surely be exploited in the future, but how far off this is we do not know. Meanwhile, in the field of glycogen storage diseases, attempts have been made to replace the missing enzyme activity by intravenous administration of a fungal enzyme of high purity which is capable of completely degrading glycogen (Baudhuin et al, 1964; Hug and Schubert, 1967; Lauer, Mascarinas, Racela, Diehl, and Brown, 1968; and Fernandes and Huijing, 1968). Preliminary reports along these lines, but utilizing a human placental $\alpha$-glucosidase, have been reported by Hers and de Barsy (1973). Such enzyme replacement therapy in children who were surely to die were, however, without clear-cut benefit.

The problem of injecting unshielded protein is fraught with difficulties, one of which is the possible immunological response. We have been investigating the possibility of entrapping enzymes of potential therapeutic use in physiologically acceptable lipid layers (called liposomes). Such sequestering of the enzyme results, upon intravenous injection into rats of liposomes containing the enzyme, in their rapid disappearance from the circulation. In the serum the enzyme remains inside the lipid envelope and thus it is not able to interfere with the normal function of the blood components. The rapid disappearance from the serum is accompanied by uptake by the liver (parenchymal and Kupffer cells are both apparently involved) and by the spleen. The enzyme so entrapped can eventually be found in the lysosomes of the liver. This work (Gregoriadis, Leathwood, and Ryman, 1971; Gregoriadis and Ryman, 1972a and b), which is still in its early stages, encourages us to think that liposomes may be a possible way of delivering enzymes into defective cells and may be important in the therapy of storage diseases, particularly those where the lysosomes are involved, such as the liver type II glycogen storage disease.
Many problems still need to be answered. For example, type I glycogen storage disease poses many problems and the activity of the missing enzyme glucose-6-phosphatase and its physiological significance is poorly understood (for review of glucose6-phosphatase see Ryman and Whelan, 1971). Glucose-6-phosphatase requires phospholipids for its activity and in vivo is firmly bound to the endoplasmic reticulum. The enzyme has never been satisfactorily purified due to this membrane dependency, although such work is under consideration (Garland and Cori, 1972). It may be questioned whether type I glycogen storage disease is a true glucose-6-phosphatase deficiency; could it be that some structural component of the endoplasmic reticulum which is required by the enzyme is missing? Such a possibility has been considered by Gluecksohn-Waelsch and Cori (1970), and more recently by Spycher and Gitzelmann (1971 and 1972), who have reported abnormalities of the endoplasmic reticulum in parenchymal cells obtained from the liver and from a stemmed liver tumour from a type I glycogen storage disease patient. They described this abnormality as an uncommon type of vesiculation of the rough endoplasmic reticulum, and it is perhaps of some interest that Stetten and Ghosh (1971) found that the rough areas of endoplasmic reticulum were associated with the more active form of glucose-6phosphatase. Several observations, both on glucose6-phosphatase-deficient mice (Russell, Cori, and Gluecksohn-Waelsch, 1970; and GluecksohnWaelsch and Cori, 1970) and on the enzyme level of a parent of two type I glycogen storage disease children (Ryman and Chung, 1969), suggest that a simple autosomal recessive mechanism would not easily satisfy the observations.

Type II glycogen storage disease also possesses problems since several authors (see de Barsy and Hers, 1973; and Eto and Takeuchi, 1973) have observed that glycogen is not the only substance that accumulates, but also a basophilic metachromatic type or material. The missing $\alpha$-glucosidase might well be involved in the catabolism of such a substance or, alternatively, a further, hitherto unobserved, defect may be present. It is of considerable interest that Hallgren, Hansson, Henriksson, Hager, Lundblat, and Svenssons (1974, personal communication) have observed the excretion of a tetrasaccharide in the urine of a type II patient.

In type $\mathrm{V}$ glycogen storage disease (lack of muscle phosphorylase) it has been reported that muscle fibres from an affected patient grown in culture regain their phosphorylase (Roelofs et al, 1972). It is possible that the well documented observations that type $\mathrm{V}$ glycogen storage disease patients often appear quite normal until their teens may be 
explained by the development of some factor which represses the production of the enzyme or leads to its inactivation, and this factor is lost or overcome in culture? It is conceivable that the muscles of type VII glycogen storage disease patients can manage without the key enzyme of glycolysis, phosphofructokinase, or are there other pathways in muscle for metabolising glucose that have up to date been considered of only very minor interest?

There is little doubt that biochemistry and medicine advance together, and the glycogen storage diseases are a good example of this. Up to 1956 it was firmly believed that phosphorylase catalysed both the synthesis and degradation of glycogen. However, type $\mathrm{V}$ glycogen storage disease appeared to be an anomalous condition in which excessive glycogen was stored in spite of the total absence of phosphorylase. This fact, and many other considerations, led to the work of Leloir and Cardini (1957) who showed that two separate pathways for synthesis and degradation existed. It is to be hoped that collaboration in the two fields will continue and that the glycogen storage diseases and their study will continue to contribute to our knowledge of biochemistry, and that biochemistry will continue to further our understanding of the clinical aspects of these disorders.

Financial support from the Wellcome Trust is gratefully acknowledged.

\section{References}

Badoual, J., Lestradet, H., Tichet, J., Sanna, N., and Grenet, P. (1972). Glycogénoseshépatiques sans déficit enzymatique reconnu se compontant cliniquement et biologiquement comme le type 1 de Cori. Ann. Pédiat., 19, 507-514.

Barsy, T. de, Jacquemin, P., Devos, P., and Hers, H. G. (1972). Rodent and Human $\alpha$-glucosidase. Europ. J. Biochem., 31, 156-165.

Baudhuin, P., Hers, H. G., and Loeb, H. (1964). An electror. microscopic and biochemical study of type II glycogenosis. Lab. Invest., 13, 1139-1152.

Bierich, J. R., Rager, K., and Schönberg, D. (1973). Endocrinological findings in patients with glycogenosis. (Abstr.) Acta endocr. (Kbh.), Suppl. 173, 128.

Brandt, I. K., and DeLuca, V. A., Jr. (1966). Type III glycogenosis: a family with an unusual tissue distribution of the enzyme lesion. Amer. J. Med., 40, 779-784.

Brown, B. I., and Brown, D. H. (1968). Glycogen-storage diseases types I, III, IV, V, VII, and unclassified glycogenoses. In Carbohydrate Metabolism and its Disorders, edited by F. Dickens, P. J. Randle, and W. J. Whelan, vol. 2, pp. 123-150. Academic Press, New York and London.

Brown, B. I., and Brown, D. H. (1972). Dynamic studies of glycogen metabolism in glycogen storage disease using fibroblast cultures derived from patients and their families. In Biochemistry of the Glycosidic Linkage: PAABS Symposium, edited by R. Piras and H. G. Poutis, pp. 687-710.

Brunberg, J. A., McCormick, W. F., and Schochet, S. S., Jr. (1971). Type III glycogenosis. Arch. Neurol., 25, 171-178.

Bruni, C. B., and Paluello, F. M. (1970). A biochemical and ultrastructural study of liver muscle, heart and kidney in type II glycogenosis. Virchows Arch. Abt. B. Zellpth., 4, 196-207.

Canal, N., Frattola, L., and Pellegrini, G. (1972). Skeletal muscle glycogenosis type II: biochemical and electron-microscopic investigations of one case. $Z$. Neurol., 201, 98-108.

Courtecuisse, V., Royer, P., Habib, R., Monnier, C., and Demos, J. (1965). Glycogénose musculaire par deficit d'alpha -1-4glucosidase simulant une dystrophie musculaire prognessiue. Arch. franc. Pédiat., 22, 1153-1164.

Cuttino, J. T., Jr., Summer, G. K., and Hill, H. D. (1970). Treatment of eruptive xanthomas in Cori type I glycogenosis. Arch. Derm., 101, 469-471.

Czapek, E. E., Deykin, D., and Salzman, E. W. (1972). Platelet dysfunction in glycogen storage disease type I. Fed. Proc., 31, Abs. 242.

Dawson, D. M., Spon, F. L., and Harrington, J. F. (1968). McArdle's disease. Ann. intern. Med., 69, 229-235.

Deckelbaum, R. J., Russell, A., Shapira, E., Cohen, T., Agam, G., and Gutman, A. (1972). Type III glycogenosis: atypical enzyme activities in blood cells in two siblings. J. Pediat., 81, 955-961.

DiMauro, S., Rowland, L. P., and Mellman, W. J. (1973). Glycogen metabolism of human diploid fibroblast cells in culture. I Studies of cells from patients with glycogenosis types II, III, and V. Pediat. Res., 7, 739-744.

Dosman, J., Crawhill, J., Klassen, G., Mamer, S. O., and Neumann, P. (1972). Short chain dicarboxylic acids appearing in urine in glycogen storage disease type I. In Proceedings of the 8th Meeting of the Federation of European Biochemical Societies, Amsterdam, p. 960.

Dreyfus, J. C., and Alexandre, Y. (1971). Immunological studies on glycogen storage disease types III and V: demonstration of the presence of an immunoreactive protein in one case of muscle phosphylase deficiency. Biochem. biophys. Res. Commun., 44, 1364-1370.

Dykes J. R. W., and Spencer-Peet, J. (1972). Hepatic glycogen synthetase deficiency. Arch. Dis. Child., 47, 558-563.

Engel, A. G. (1970). Acid maltase deficiency in adults. Brain, 93, 599. 616.

Epand, R. M., and Douglas, R. J. (1973). The effect of glucagon antibodies on plasma glucose and insulin levels. Biochim. biophys. acta (Amst.) 320, 741-744.

Eto, K., and Takeuchi, T. (1973). An autopsy case of glycogen and non-glycogen polysaccharide storage disease with cardiomegaly. Acta path. jap. 23, 189-209.

Fernandes, J., and Huijing, F. (1968). Branching enzyme-deficiency glycogenosis studies in therapy. Arch. Dis. Child., 43, 347-352

Fernandes, J., Huijing, F., and Kramer, van de J. H. (1969). A screening method for liver glycogen diseases. Arch. Dis. Child. 44, 311-317.

Fernandes, J., and Pikaar, N. A. (1969). Hyperlipemia in children with liver glycogen disease. Amer. J. clin. Nutr., 22, 617-627.

Fernandes, J., and Pikaar, N. A. (1972). Ketosis in hepatic glycogenosis. Arch. Dis. Child., 47, 41-46.

Fernandes, J., and Kramer, van de J. H. (1968). Hexose + protein tolerance tests in children with liver glycogenosis caused by a deficiency of the debranching enzyme system. Pediatrics, 41, 935-944.

Fine, R. N., Frasier, S. D., and Donnell, G. N. (1969). Growth in glycogen storage disease type I. Amer. J. Dis. Child., 117, 169-177.

Fine, R. N., Wilson, W. A., and Donnell, G. N. (1968). Retinal changes in glycogen storage disease type I. Amer.J. Dis. Child., $115,328-331$.

Folkman, J. Philippart, A., Tze, W. J., and Crigler, J., Jr. (1972). Portacaval shunt for glycogen storage disease: value of prolonged intravenous hyperalimentation before surgery. Surgery, 72, 306-314.

Garancis, J. C. (1968). Type II glycogenosis. Amer. J. Med., 44, 289300.

Garland, R. C., and Cori, C. F. (1972). Separation of phospholipids from glucose 6-phosphatase by gel chromatography. Specificity of phospholipid reactivation. Biochemistry, 11, 4712-4718.

von Gierke, E. (1929). Hepato-nephromegalis-glykogenica (glykogenspeicherkrankheit der Rieber und nieren). Beitr. path. Anat., 82, 497-513.

Gluecksohn-Waelsch, S., and Cori, C. F. (1970). Glucose 6-phosphatase deficiency: mechanism of genetic control and biochemistry. Biochem. Genet., 4, 195-202.

Gregoriadis, G., Leathwood, P. D., and Ryman, B. E. (1971). Enzyme entrapment in liposomes. FEBS Letters, 14, 95-99.

Gregoriadis, G., and Ryman, B. E. (1972a). Fate of protein-containing liposomes injected into rats. Europ. J. Biochem., 24, 485-491.

Gregoriadis, G., and Ryman, B. E. (1972b). Lysosomal localisation of $\beta$-fructofuaanoside-containing liposomes injected into rats. 
Some implications in the treatment of genetic disorders. Biochem. J., 129, 123-133.

Grenet, P., Badoual, J., Lestradet, H., Marinetti, J., Sanna, N., and Voyer, J. (1972). Un cas de glycogénase avec hypoglycémies itératives sans déficit d'attivité enzymatique á la biopsie hépatique. Ann. Pédiat., 19, 499-506.

Gruener, R., McArdle, B., Ryman, B. E., and Weller, R. O. (1968). Contracture of phosphorylase deficient muscle. J. Neurol. Neurosurg. Psychiat., 31, 268-283.

Gunja-Smith, Z., Marshall, J. J., Mercier, C., Smith, E. E., and Whelan, W. J. (1970). A revision of the Meyer-Bernfeld model of glycogen and amylopectin. FEBS Letters, 12, 101-104.

Hallgren, P., Hansson, G., Henriksson, K. G., Hager, A., Lundblat, A., and Svenssons, (1974). Increased excretion of a glucose containing tetrasaccharide in the urine of a patient with type II (Personal communication).

Hermann, R. E., and Mercer, R. D. (1969). Portacaval shunt in the treatment of glycogen storage disease. Surgery, 65, 499-503.

Hers, H. G. (1964). Glycogen storage disease. Advanc. metab. Dis., 1, 1-44.

Hers, H. G., and Barsy, T. de (1973). Type II glycogenosis (acid maltose deficiency). In Lysosomes and Storage Diseases, edited by H. G. Hers, and F. Van Hoof, pp. 197-216. Academic Press, New York and London.

Hers, H. G., and van Hoof, F.: (1968). Glycogen-storage diseases: type II and type VI glycogenesis. In Carbohydrate Metabolism and its Disorders, edited by F, Dickens, P. J. Randle, and W. J. Whelan, vol. 2, pp. 151-168. Academic Press, New York and London.

Van Hoof, F. (1967). Amylo-1,6,-glucosidase activity and glycogen content of the erythrocytes of normal subjects, patients with glycogen storage disease and heterozygotes. Europ. J. Biochem. 2, 271-274.

Van Hoof, F., and Hers, H. G. (1967). The subgroups of type III glycogenosis. Europ. J. Biochem., 2, 265-270.

Howell, R. R. (1972). The glycogen storage diseases. In The Metabolic Basis of Inherited Disease, edited by J. B. Stanbury, J. B. Wyngaarden, and D. S. Fredrickson, 3rd ed., pp. 149-173. McGraw-Hill, New York.

Howell, R. R., Ashton, D. M., and Wyngaarden, J. B. (1962). Glucose 6-phosphatase deficiency glycogen storage disease: studies on the interrelationships of carbohydrate, lipid, and purine abnormalities. Pediatrics, 29, 553-565.

Hudgson, P., Gardner-Medwin, D., Worsfold, M., Pennington, R. J. T., and Walton, J. N. (1968). Adult myopathy from glycogen storage disease due to acid maltase deficiency. Brain, 91, 435-462.

Hue, L., and Hers, H. G. (1972). The turnover of $(2-3 \mathrm{H})$ glucose: an assay for diagnosis of type I glycogenosis. In Biochemistry of the Glycosidic Linkage: PAABS Symposium, edited by $\mathrm{R}$. Piras and H. G. Poutis, pp. 681-687. Academic Press, New York and London.

Hug, G., Garancis, J. C., Schubert, W. K., and Kaplan, S. (1966.) Glycogen storage diseases, types II, III, VIII, and IX. Amer. J. Dis. Child., 3, 457-474.

Hug, G., and Schubert, W. K. (1967). Lysosomes in type II glycogenosis. J. Cell Biol., 35, C1-C6.

Hug, G., Schubert, W. K., and Chuck, G. (1966). Phosphorylase kinase of the liver: deficiency in a girl with increased hepatic glycogen. Science, 153, 1534-1535, and $J$. clin. Invest., 48, 704 715.

Hug, G., Schubert, W. K., and Chuck, C. (1969). Deficient activity of dephosphophosphorylase kinase and accumulation of glycogen in the liver. J. clin. Invest., 48, 704-715.

Hug, G., Schubert, W. K., and Chuck, G. (1970a). Letter to Editor and reply by F. Huijing and J. Fernandes. Amer. J. hum. Genet., 22, 484-485.

Hug, G., Schubert, W. K., and Chuck, G. (1970b). Loss of cyclic 3'5'AMP dependent kinase and reduction of phosphorylase kinase in skeletal muscle of a girl with deactivated phosphorylase and glycogenosis of liver and muscle. Biochem. biophys. Res. Commun., 40, 982-988.

Hug, G., Schubert, W. K., and Soukup, S. (1970c). Prenatal diagnosis of type-II glycogenosis. (Letter) Lancet, 1, 1002.

Hug, G., Schubert, W. K., and Soukup, S. (1971). Ultrastructure and enzymic deficiency of fibroblast cultures in type II glycogenosis. Pediat. Res., 5, 107-112.

Hug, G., Sper, M. R., and Schubert, W. K. (1973). Adult versus infantile glycogenosis in type II. (Abstr.) Pediat. Res., 7, 389.
Huijing, F. (1968). Enzymes of glycogen metabolism in leucocytes in relation to glycogen-storage disease. In Control of Glycogen Metabolism (FEBS Symposia), edited by W. J. Whelan, pp. 115-128. Universitetsforlaget, Oslo. Academic Press, London and New York.

Huijing, F. (1970a). Phosphorylase kinase deficiency. Biochem. Genet., 4, 187-194.

Huijing, F. (1970b). Glycogen-storage disease type VIa: low phosphorylase kinase activity caused by a low enzyme substrate affinity. Biochem. biophys. Acta (Amst.), 206, 199-201.

Huijing, F., and Fernandes, J. (1969). X-chromosomal inheritance of liver glycogenosis with phosphorylase kinase deficiency. Amer. J. hum. Genet., 21, 275-284.

Huijing, F., Lee, E. Y. C., Carter, J. H., and Whelan, W. J. (1970). Branching action of amylo-1, 6-glucosidase/oligo-1, $4 \rightarrow 1$, 4-glucantransferase. FEBS Letters, 7, 251-254.

Huijing, F., Obbink, H. J. K., and Creveld, S. van (1968). The activity of the debranching enzyme system in leucocytes. Acta genet. (Basel), 18, 128-136.

Kelley, W. N., Rosenbloom, F. M., Seegmiller, J. E., and Howell, R. R. (1968). Excessive production of uric acid in type I glycogen storage disease. J. Pediat., 72, 488-496.

Koster, J. F., Fernandes, J., Slee, R. G., Berkel, Th. J. C. van, and Hülsmann, W. C. (1973). Hepatic phosphorylase deficiency: a biochemical study. Biochem. biophys. Res. Commun., 53, 282290.

Lauer, R. M., Mascarinas, T., Racela, A. S., Diehl, A. M., and Brown, B. I. (1968). Administration of a mixture of fungal glucosidases to a patient with type II glycogenosis. Pediatrics, 42, 672-676.

Layzer, R. B., Rowland, L. P., and Ranney, H. M. (1967). Muscle phosphofructo-kinase deficiency. Arch. Neurol., 17, 512-523.

Leathwood, P. D., and Ryman, B. E. (1971). Enzyme of glycogen metabolism in human skin with particular reference to differential diagnosis of the glycogen storage diseases. Clin. Sci., 40, 261-269.

Leloir, L. F., and Cardini, C. E. (1957). Biosynthesis of glycogen from uridine diphosphate glucose. J. Amer. Chem. Soc., 79, 63406341

Levin, S., Moses, S. W., Chayoth. R., Jagoda, N., and Steinitz, K. (1967). Glycogen storage disease in Israel. Israel J. med. Sci. 3, 397-410.

Levin, B., Burgess, E. A., and Mortimer, P. E. (1968). Glycogen storage disease type IV, amylopectinosis. Arch. Dis. Child., 43, 548-555.

Lockwood, D. H., Merimee, T. J., Edgar, P. J., Greene, M. L., Fujimoto, W. Y., Seegmiller, J. E., and Howell, R. R. (1969). Insulin secretion in type I glycogen storage disease. Diabetes, 18, 755-758.

Lowe, C. U., Ambrus, J. L., Ambrus, C. M., Mosovitch, J. L., Mink, I. B., and Sokal, J. E. (1960). Beldeing diathesis in children with liver glycogen disease and their parents. (Abstr.), J. clin. Invest., 39, 1007-1008.

Ludwig, M., Wolfson, S., and Rennert, O. (1972). Glycogen storage disease type VIII. Arch. Dis. Child., 47, 830-833.

Lundquist, A., and Öckerman, P. A. (1970). Fine-needle aspiration biopsy of human liver for enzymatic diagnosis of glycogen storage disease and gargoylism. Acta. paediat. scand., 59, 293-296.

Mathieu, M., Collombel, C., and Cotte, J. (1972). Phosphomylase activity in white blood cells and skin fibroblasts in type VI glycogenosis. (Abstr.). Scand. J. clin. Invest., 29, Suppl. 126, Abs. 23-48.

Mercier, C., and Whelan, W. J. (1970). The fine structure of glycogen from type IV glycogen storage disease. Europ. J. Biochem., 16, 579-583.

Miller, C. G., Alleyne, G. A., and Brooks, S. E. H. (1972). Gross cardiac involvement in glycogen storage disease type III. Brit. Heart $J ., 34,862-864$.

Moe, P. J., Garatun-Tjeldstø, E., Garatun-Tjeldstø, O., Raae, A. F. and Vogt, J. (1972). Glycogen storage disease in Norway. Acta paediat. scand., 61, 536-543.

Moe, P. J., Waaler, P. E., and Garatun-Tjeldstø, O. (1972). Glycogen storage disease type III and diabetes mellitus. Acta paediat. scand., 61, 483-486.

Morishita, Y., Nishiyama, K., Yamamura, H., Kodama, S., Negishi, H., Matsuo, M., Matsuo, T., and Nishizuka, Y. (1973). Glycogen phosphorylase kinase deficiency. Biochem. biophys. Res. Commun., 54, 833-841.

Moses, S. W. (1973). Glycogen storage disease type IB: presentation of an unusual case. (Abstr.) Israel J. med. Sci., 9, 1106. 
Motoi, M., Sonobe H., Ogawa, K., Murakami, M., Yamanouchi, I., Toda, H. Okamoto, T., and Ohara, T. (1973). Two autopsy cases of glycogen storage disease-cirrhotic type. Acta path. jap., 23, 211-223.

Nadler, H. L., and Messina, A. M. (1969). In-utero detection of typeII glycogenosis (Pompe's disease). Lancet, 2, 1277-1278.

Nixon, J. C., Hobbs, W. K., and Greenblatt, J. (1966). Myoglobinuria and skeletal muscle phosphorylase deficiency. Canad. med. Ass. J., 94, 977-985.

Ockerman, P. A. (1965a). Glucose, glycerol and free fatty acids in glycogen storage disease type $\mathbf{I}$. Blood levels in the fasting and non-fasting state. Effect of glucose and adrenalin administration. Clin. chim. Acta, 12, 370-382.

Öckerman, P. A. (1965b). In vitro studies of adipose tissue metabolism of glucose, glycerol and free fatty acids in glycogen storage disease type I. Clin. chim. Acta., 12, 383-388.

Öckerman, P. A. (1967). The diagnosis of glycogen storage diseases in clinical practice. Israel J. med. Sci., 3, 494-498.

Ockerman, P. A. (1968). A technique for the enzymic diagnosis of glycogen storage disease on very small tissue specimens. Acta paediat. scand., 57, 105-109.

Öckerman, P. A. (1972). Incidence of glycogen storage disease in Sweden. Acta paediat. scand., 61, 533-535.

Ockerman, P. A., Jelke, H., and Kaijser, K. (1966). Glycogenosis type 6 (liver phosphorylase deficiency). Acta paediat. (Uppsala), $55,10-16$.

Owen, O. E., Morgan, A. P., Kemp, H. G., Sullivan, J. M., Herrera, M. G., and Cahill, G. F., Jr. (1967). Brain metabolism during fasting. $J$. clin. Invest., 46, 1589-1595.

Pernow, B. B., Havel, R. J., and Jennings, D. B. (1967). The second wind phenomenon in McArdle's syndrome. Acta med. scand., Suppl., 472, 294-307.

Riddell, A. G., Davies, R. P., and Clark, A. D. (1966). Portacaval transposition in the treatment of glycogen storage disease. Lancet, 2, 1146-1148.

Roelofs, R. I., Engel, W. K., and Chauvin, P. B. (1972). Histochemical phosphorylase activity in regenerating muscle fibers from myophosphorylase-deficient patients. Science, 177, 795797.

Roth, J. C., and Williams, H. E. (1967). The muscular variant of Pompe's disease. J. Pediat., 71, 567-573.

Russell, J. D., Cori, C. F., and Gluecksohn-Waelsch. S. (1970). Further studies on the X-ray induced genetic loss of glucose 6-phosphatase in liver and kidney of mice. In Metabolic Regulation and Enzyme Action (FEBS Symposia), edited by A. Sols and S. Grisolia, vol. 19, pp. 315-324. Academic Press, London and New York.

Ryman, B. E. and Chung, T. (1969). Enzyme studies in type I and type $\mathrm{V}$ glycogen storage disease. In Proceedings of the 6 th meeting of the Federation of European Biochemical Society, Madrid, p. 278.

Ryman, B. E., and Whelan, W. J. (1971). New aspects of glycogen metabolism. Advanc. Enzymol., 34, 285-443.

Salafsky, I. S., and Nadler, H. L. (1971). Alpha-1, 4 glucosidase activity in Pompe's disease. J. Pediat., 79, 794-798.

Salter, R. H. (1968). The muscle glycogenoses. Lancet, 1, 1301-1304.

Salter, R. H., Adamson, D. G., and Pearce, G. W. (1967). McArdle's syndrome. Quart. J. Med., 36, 565-578.

Schmrigk, K., Mertens, H. G., Richer, K., Führ, J., Eyer, P., and Pette, D. (1967). McArdle-syndrome (myopathie bel fehlender muskel phosphorylase). Klin. Wschr. 47, 1-17.

Schochet, S. S., Jr., McCormick, W. F., and Kovarsky, J. (1971). Light and electron microscopy of skeletal muscle in type IV glycogenosis. Acta neuropath. (Berlin), 19, 137-144.
Schochet, S. S., Jr., McCormick, W. F., and Zellweger, H. (1970). Type IV glycogenosis (amylopectinosis). Arch. Path., 90, 354-363.

Schotland, D. L., Spiro, D., Rowland, L. P., and Carmel, P. (1965). Ultra structural studies of muscle in McArdle's disease. $J$. Neuropath. exp. Neurol., 24, 629-644.

Shen, L. C., Edstrom, R. D., and Larner, J. (1972). Primer activity of a low molecular weight glycogen from a patient with an unusual glycogen storage disease. Physiol. Chem. Phys., 4, 56-60.

Sidbury, J. B., Jr. (1965). The genetics of the glycogen storage diseases. Progr. med. Genet., 4, 32-58.

Smith, E. E. Taylor, P. M., and Whelan, W. J. (1968). Enzymic processes in glycogen metabolism. In Carbohydrate Metabolism and its Disorders, edited by F. Dickens, P. J. Randle, and W. J Whelan, vol. 1, pp. 89-138. Academic Press, London and New York.

Spencer-Peet, J., Norman, M. E., Lake, B. D., McNamara, J., and Patrick, A. D. (1971). Hepatic glycogen storage disease. Quart. J. Med., 157, 95-114.

Spycher, M. A., and Gitzelmann, R. (1971). Glycogenosis type I (glucose-6-phosphatase deficiency): ultrastructural alterations of hepatocytes in a tumor bearing liver. Virchows Arch. Abt. B. Zellpath., 8, 133-142, and Pediat. Res., (1972), 6, 55.

Starzl, T. E., Brown, B. I., Blanchard, H., and Brettschneider, L. (1969). Portal diversion in glycogen storage disease. Surgery, 65, 504-506.

Starzl, T. E., Marchioro, T. L., Sexton, A. W., Illingworth, B., Waddell, W. R., Faris, T. D., and Herrmann, T. J. (1965). The effect of portacaval transposition on carbohydrate metabolism: experimental clinical observations. Surgery, 57, 687-697.

Stetten, M. R., and Ghosh, S. B. (1971). Different properties of glucose-6-phosphatase and related enzymes in rough and smooth endoplasmic reticular membranes. Biochem. biophys. Acta (Amst.), 233, 163-175.

Tarui, S., Okuno, G., Ikura, Y., Tanaka, T., Suda, M., and Nishikawa, M. (1965). Phosphofructokinase deficiency in skeletal muscle: a new type of glycogenosis. Biochem. biophys. Res. Commun., 19, 517-523.

Taylor, P. M., and Whelan, W. J. (1968). Rabbit muscle amylo-1, 6-glucosidase: properties and evidence of heterogeneity. In Control of Glycogen Metabolism (FEBS Symposia, no. 5) edited by W. J. Whelan, pp. 101-114, Universitetsforlaget, Oslo, and Academic Press, London and New York.

Thomson, W. H. S., MacLaurin, J. C., and Prineas, J. W. (1963). Skeletal muscle glycogenosis: an investigation of two dissimilar cases. J. Neurol. Neurosurg. Psychiat., 26, 60-68.

Tze, W., Crigler, J. F., and Folkman, M. J. (1972). Reversal of metabolic abnormalities of type I glycogen storage disease by intravenous alimentation. (Abstr.), Pediat. Res. 6, 403.

Vítek, B., Srácková, D., Toman, M., Krátský, J., and Vognárek, J. (1970). Hypolipidaemia in type III glycogenosis. Acta paediat. scand., 59 701-705.

Waaler, P. E., Garatun-Tjeldstø, O., and Moe, P. J. (1970). Genetic studies in glycogen storage disease type III. Acta paediat. scand., 59, 529-535.

Wagner, R., Huijing, F., and Porter, E. (1971). Hepatic glycogenosis due to phosphorylase deficiency. Amer. J. Med., 51, 685-691.

Williams, C., and Field, J. B. (1968). Studies in glycogen storage disease. III. Limit dextrinosis: a genetic studies. J. Pediat., 72, 214-221.

Zellweger, H., Mueller, S., Ionasescu, V., Schochet, S. S., and McCormick, W. F. (1972). Glycogenosis IV: a new cause of infantile hypotonia. J. Pediat., 80, 842-844. 